\title{
人工血管感染に対する再手術症例の検討
}

\begin{tabular}{|c|c|c|c|c|c|c|c|c|c|c|c|c|c|}
\hline 伊 藤 & 健 & 造 & 北 & 川 & 哲 & 也 & 北 & 市 & & 隆 & 福 & 田 & \\
\hline 筑 後 & 文 & 雄 & 川 & 人 & 智 & 久 & 田 & 埜 & 和 & 利 & 堀 & & 隆 \\
\hline & & & 吉 & 栖 & 正 & 典 & 加 & 藤 & 逸 & 夫 & & & \\
\hline
\end{tabular}

\begin{abstract}
治療に難渋した人工血管感染 5 症例について検討した。年齢は 57 ～ 81 歳，初回手術時の基礎疾患は Leriche 症候群 1 例を含む閉塞性動脈硬化症 3 例，覀性腫瘍の動脈浸潤 2 例であった。人工血管感染 部位は鼠蹊部 3 例, 膝上部 1 例, 腹部 1 例で, うち 4 例の起炎菌はStaph. aureus（MRSA3 例） であった，感染原因となった人工血管の手術から感染発現までの期間は，腹膜炎症例は 10 日と短く， 末梢側の感染では 2 か月〜 14 年と長かった。腹膜炎例を除いた症例での感染巣のドレナージ, 洗浄 等の保存的治療期間は 40 64（平均 50) 日であった。手術はグラフトの感染部位のみの除去またはグ ラフト全部を摘出し, 新たな血行再建術を施行した。感染グラフトは PTFE4 例, Woven-Dacron 1 例で，再手術にも同様のグラフトを用いた。感染部を避けるため，閉鎖孔経由など 3 例で別経路を用 いた，感染人工血管の全摘出が困難な症例では，感染巣部のみの人工血管摘除と健常な周囲組織での 再建術を行い良好な結果を得た。手術成績は全例生存, 敗血症や下肢切断等の重篤な合併症は認めな かった. 再手術から現在までの 8 か月 8 年間, 全例開存し再感染も認めていない. 日心外会誌 26 巻 1 号 : 40-45 (1997)
\end{abstract}

Keywords : 人工血管感染, 非解剖学的バイパス, 閉鎖孔バイパス, 筋肉充塡

\section{Surgical Therapy for Prosthetic Graft Infection}

Kenzo Itoh, Tetsuya Kitagawa, Takashi Kitaichi, Yasushi Fukuta, Fumio Chikugo, Tomohisa Kawahito, Kazutoshi Tano, Takaki Hori, Masanori Yoshizumi and Itsuo Katoh (Department of Cardiovascular Surgery, School of Medicine, The University of Tokushima, Tokushima, Japan) Five patients with vascular graft infections were surgically treated over a 16-year period. Primary diseases were arteriosclerosis obliterans in 3 cases and invasion of malignant diseases in 2 cases. The most common site of infection was the groin (3 of 5). Staphylococcus aureus was the most common pathogen. Administration of antibiotics, drainage and lavage with povidone iodine solution were performed in 4 patients (40-64 days). All patients underwent graft resection and reconstruction. Infected parts of the previous grafts were removed. Total removal of the previous graft was performed in 2 cases and partial removal was performed in 3 cases. To avoid re-infection, long extra-anatomical bypass was performed in 4 cases. The post operative courses of the five patients were uneventful. Jpn. J. Cardiovasc. Surg. 26 : 40-45 (1997)

血行再建術後のグラフト感染は治療に難渋する ことが多く，保存的治療の期間や再手術の方法に ついてさまざまな報告がある。われわれは人工血 管感染をきたした 5 症例に対して再手術を施行 し，良好な結果を得たので報告する。

対 象

1979 年から 1995 年までに血行再建術を施行し た 172 例中，術後早期または遠隔期に感染を認め

1996 年 2 月 28 日受付, 1996 年 5 月 30 口採用

徳島大学心臟血管外科 $\overline{7} 770$ 徳島市蔵本町 2-50-1
た 5 例を対象とした。

年齢は 57 から 81 歳, 平均 63.6 歳で, 性別は 男性 4 例，女性 1 例である. 初回手術時の基礎疾 患は Leriche 症候群 1 例を含む閉塞性動脈硬化症 3 例, 悪性腫瘍の動脈浸潤 2 例であった（図 1 , 2).

\section{結果}

感染率は $2.9 \%$ でる。

前回までの手術は腸骨大腿動脈（I-F）バイパ ス 3 例（うち交叉バイパス 1 例), 大腿㯟窩動脈 


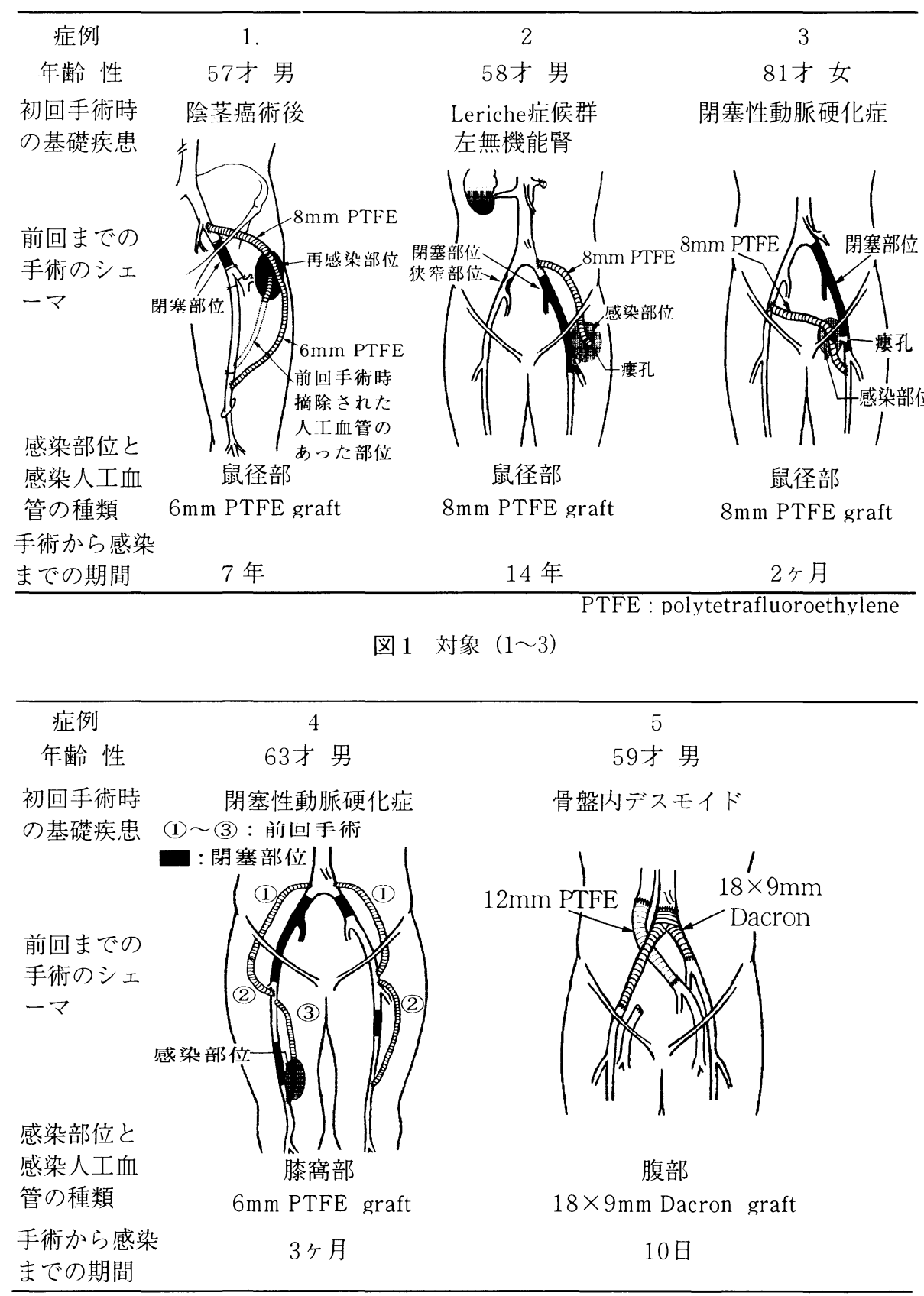

図 2 対象 $(4,5)$

（F-P）バイパス 1 例，大動脈両側腸骨動脈（AobiI）バイパス 1例であった。

部位抒よび発生までの期間：I-F バイパス例は いずれも鼠蹊部に感染をきたした。症例 1 は左大 腿動脈浸潤を呈した陰茎癌に対する放射線照射後 に左大腿動脈破裂をきたし，同部の動脈を結禁後
I-Fバイパスを置いたが，1 か月後末梢側吻合部 に感染をきたしたため人工血管を遠位部分摘除し 再置換を行った。しかしその 7 年後に再置換した 人工血管と残した人工血管との吻合部に再度感染 をきたした。症例 2 は基礎疾患が Leriche 症候群 と左無機能腎で，腹部大動脈の血栓内膜摘除，左 
I-F バイパスおよび左腎摘出術を施行した 14 年 後, 末梢側吻合部に感染をきたした。症例 3 は低 心機能の高歯者で, 腸骨大腿動脈交叉バイパスの 末梢側吻合部より中枢側の左側鼠蹊部に感染をき たした。症例 4 は右 I-F バイパスの血栓による閉 塞のため人工血管末梢側の部分置換を行ったが, さらに末梢の浅大腿動脈に再狭窄をきたしたため F-P バイパスを追加した. F-P バイパス施行後 3 か月目にその末梢側吻合部に感染をきたした。症 例 5 は骨盤内デスモイド浸潤による右総腸骨動静 脈および右深部大腿静脈閉塞のため腫瘍摘出術, 右腎摘出術, 腹部大動脈掞よび下大静脈合併切除 後, Ao-biI バイパス抢よび下大静脈-左総腸骨静 脈グラフト吻合による再建を行ったが, 術後 10 日目に腹膜炎をきたし緊急手術となった。

感染原因となった人工血管の手術から感染発現 までの期間は腹膜炎症例は 10 日と短く，末梢側 の感染では 2 か月から 14 年と長い傾向があった。

感染グラフトの素材は PTFE 4 例, Woven-

Dacron 1 例であった.

起因菌：瘻孔からの膿汁や露出血管の細菌培養 は腹膜炎症例を除く 4 例で陽性で, 起炎菌は Staph. aureus が 4 例でもっとも多く, うち 3 例 は methicillin resistant Staph. aureus (MRSA) であった. 他にE. coli や Peptostreptococcus, Candida などを認めた（表 1).

治療：腹膜炎例を除いた症例の経静脈的抗生剂
投与と感染巣のドレナージ，ポビドンヨードや抗 生剤に上る洗浄等の保存的治療期間は 40 から 64 日（平均 50 日）であった。いずれの症例も感染 範囲の限局化, 炎症所見の改善が得られた。保存 的治療により炎症所見が安定化した段階で再手術 を施行した。

外科治療：手術は症例により，グラフトの感染 部位のみの除去またはグラフト全部の除去を行 い，新たな血行再建術を追加した。

再建は感染巣を避けるため症例 1,3 以外は前 回とは別経路の非解剖学的バイパスを行った（図 $3,4)$.

症例 1 は悪性腫瘍に対して左鼠踩部のリンパ節 郭清と放射線照射を施行した後, 患側下肢のリン パ浮腫と鼠蹊部皮膚の硬化をきたしていたため, グラフトの全摘除より遠位側の感染部のみの摘除 が良策と考えた。感染巣を人工血管を含めて enbloc に摘除後, 同経路で再置換術を施行し, そ の表層の組織欠損部を有茎筋皮弁にて補填した。

症例 2 は入院 40 日目に感染人工血管をすべて 除去し, デブリードマン後, $\mathrm{Y}$ 字グラフトによ る置換を行った．左側は術野と感染巣が交通しな いように閉鎖孔経由とした。

症例 3 は低心機能の高齢者で，初回手術が腸骨 大腿動脈交叉バイパスであったため，グラフトの 感染部のみの部分摘除とし，デブリードマン後に 同一経路で再建した。

表 1 保存的治療

\begin{tabular}{|c|c|c|c|c|c|}
\hline 症例 & 起炎菌 & 糖尿病 & CRP(術前最高値) & 治療内容 & 保存的治療の期間 \\
\hline 1 & $\begin{array}{l}\text { Staphylococcus aureus } \\
\text { Candida albicans }\end{array}$ & $(+)$ & 0.71 & $\mathrm{CTM}$ 投与 & 44 日 \\
\hline 2 & $\begin{array}{l}\text { Peptostreptococcus } \\
\text { Bacteriodes sp. }\end{array}$ & $(-)$ & 12.7 & $\begin{array}{l}\mathrm{CRDM}, \mathrm{SBT} / \mathrm{CPZ} \text { 投与, 瘻孔より } \\
\text { ドレーン挿入しポビドンヨードに } \\
\text { て洗浄 }\end{array}$ & 40 日 \\
\hline 3 & MRSA & $(+)$ & 10.2 & $\begin{array}{l}\text { VCM 投与, 瘻孔よりドレーン挿入 } \\
\text { し MINO, VCM にて洗浄 }\end{array}$ & 54 日 \\
\hline 4 & $\begin{array}{l}\text { MRSA } \\
\text { E.coil, Candida sp. }\end{array}$ & $(-)$ & 3.1 & $\begin{array}{l}\mathrm{VCM} \text { 投与, 瘻孔より VCM にて } \\
\text { 洗浄 }\end{array}$ & 64 日 \\
\hline 5 & $\begin{array}{l}\text { MRSA } \\
\text { Candida albicans }\end{array}$ & $(-)$ & 17.6 & 腹膜炎にて緊急手術 & - \\
\hline
\end{tabular}

CTM: Cefotiam, CRDM: Clindamycin, SBT/CPZ: Sulbactam/Cefoperazone, VCM: Vancomycin, MINO: Minocycline. 


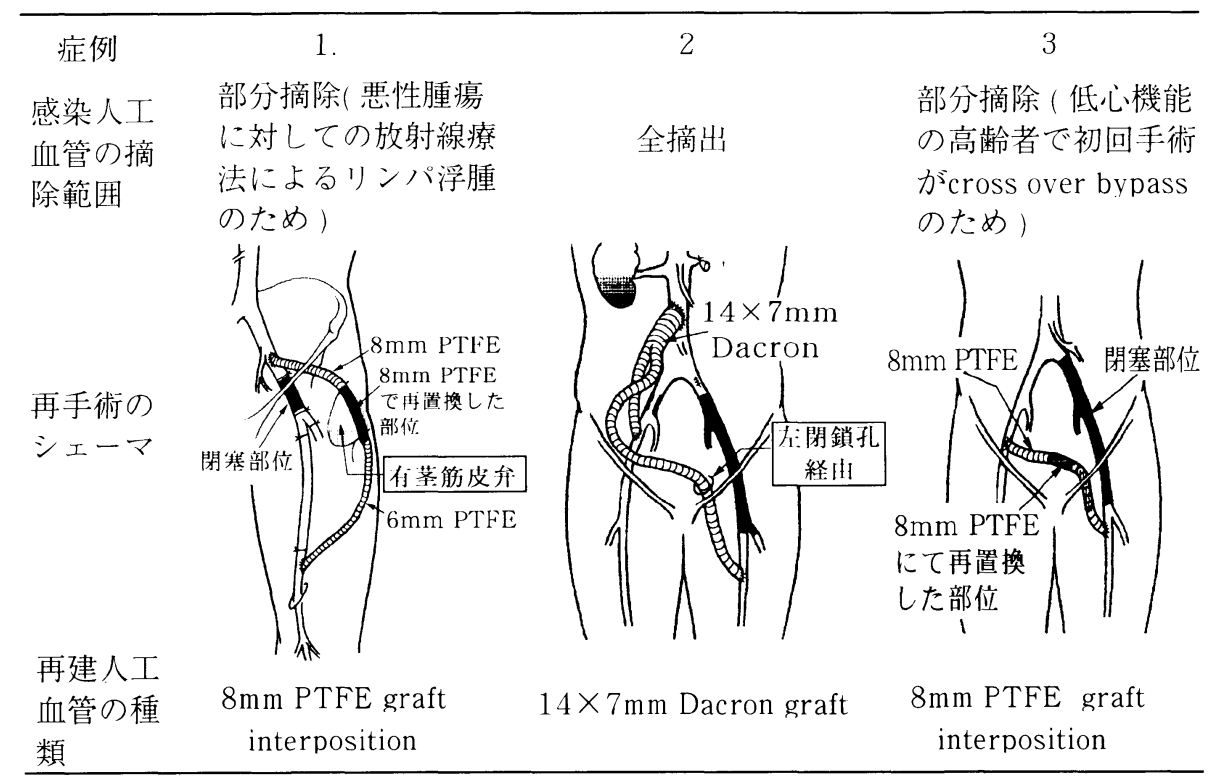

図 3 人工血管感染に対する再手術（1～3）

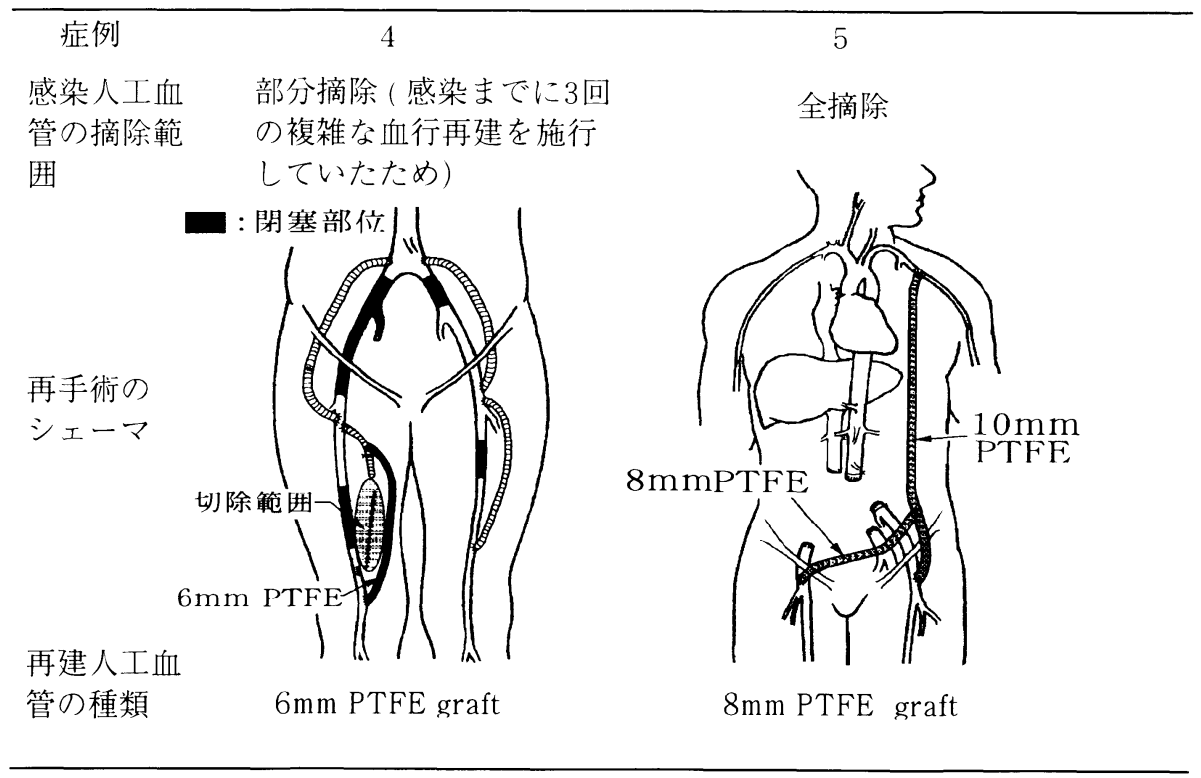

図 4 人工血管感染に対する再手術 $(4 ， 5)$

症例 4 は感染をきたす前に血管閉塞のため 3 回 の血行再建が複雑になされており, 患側人工血管 をすべて除去することは危険で，感染巣をグラフ トの遠位部を含めて健常組織まで十分に en-bloc に切除し, 未梢側の再置換を施行した.

症例 5 は MRSAによる汎発性腹膜炎のため,
保存的療法は施行せず腹腔内のグラフトを全摘出 し, 動脈再建は左腋窩両側大腿動脈バイパスを施 行した。静脈再建は行わなかった。

成績: 手術成績は全例生存, 敗血症や下肢切断 等の重篤な合併症は認めず, 現在までの 8 か月か ら 8 年間, 全例開存し, 再感染も認めていない. 


\section{考察}

人工血管の感染率は全体で 0.8 ～ $.3 \%$ と報告 されており ${ }^{1 \sim 11)}$, 当科でも $2.9 \%$ と同程度であっ た.

発生部位は鼠蹊部が 5 例中 3 例と最も多く, 他 家の報告2,4,11) と一致した。

起炎菌は以前はS. aureus が多いとされてい た ${ }^{1,4)}$ が，現在はS. epidermidis を中心とする coagulase-negative- Staphylococci (CNS) が多 くなっていると報告されている7,12 14). また八柳 $ら^{11)}$, Fletcher ら ${ }^{15)} に よ る と$ MRSA の増加が問 題となっている. 当科でも $S$. aureus が 4 例と最 も多く，そのうち 3 例は MRSA であった。

当科の感染したグラフトは, PTFEが多かっ たが，材質による易感染性の差はみられないよう である。

治療は腹膜炎症例を除き, 保存的治療により感 染が十分コントロールできた時点で再手術を施行 した。全身状態が許せば感染巣が限局されるまで 保存的治療を施行し，炎症所見が安定化した時期 に再手術を施行すべきである。

再手術は感染原因である人工血管の全摘出, 創 部の十分なデブリードマンと新たな血行再建術が 原則と思われるが，症例によっては全摘出が良策 でない場合も多い。

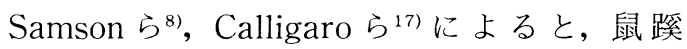
部より末梢の動脈の感染ではグラフトの全摘出は 死亡率, 四肢切断率が高く, 感染部だけの人工血 管摘出でも良好な成績が示されている。手術侵襲 を軽減するうえでは，感染巣部のみの人工血管摘 除と健常な周囲組織での再建術も考慮されるべき である。

再建人工血管については最近 rifampicinに浸 潤させた protein-sealed Dacron graft はStaph. aureus 感染に対し抵抗性が増すという報告 ${ }^{16)}$ が あり，その意味で今後使用してもよい人工血管と 思われる。

再建経路は再感染の危険を避けるため, 可能な 限り非解剖学的バイパスを選択するのが一般的で ある ${ }^{10,17 \sim 20)}$.

われわれの症例では，末梢の run off が良好で
あれば比較的長いルートでも良好な開存率が得ら れた。原疾患が悪性腫瘍の 2 症例はいずれも run off 良好で，現在まで 8 か月から 8 年間，全例開 存している.

また多数回手術による痏痕あるいは感染巣によ り再建ルートが制限される症例では, 新人工血管 を有茥筋皮弁で被覆した同一経路の再建術も有用 と思われた。

いずれにしても個々の症例に応じて感染巣内の 人工血管を摘出し，安全な経路による新たな血行 再建術を施行すべきである。

\section{文献}

1) Liekweg, W.G. Jr. and Greenfield, L.J. : Vascular prosthetic infections: Collected experience and results of treatment. Surgery $81: 335-342$, 1977.

2) Landreneau, M.D. and Raju, S.: Infections after elective bypass surgery for lower limb ischemia: The influence of preoperative transcutaneous arteriography. Surgery 90 : 956-961, 1981.

3) Bunt, T.J.: Synthetic vascular graft infections. : I. Graft infections. Surgery 93: 733746, 1983.

4) Lorentzen, J.E., Nielsen, O.M., Arendrup, H. et al. : Vascular graft infection: An analysis of sixty-two graft infections in 2411 consecutively implanted synthetic vascular grafts. Surgery 98: 81-86, 1985.

5) Szilagyi, D.E., Elliot, J.P.Jr., Smith, R.F. et al. : A thirty-year survey of the reconstructive surgical treatment of aortoiliac occlusive disease. J. Vasc. Surg. 3: 421-436, 1986.

6) O'Hara, P.J., Hertzer, N.R., Beven, E.G. et al. : Surgical management of infected abdominal aortic grafts: Review of a 25-year experience. J. Vasc. Surg. 3 : 725-731,1986.

7) Bunt, T.J.: Vascular graft infections: a personal experience. Cardiovasc. Surg. 1: 489493, 1993.

8) Samson, R.H., Veith, F.J., Janko, G.S. et al. : A modified classification and approach to the management of infections involving peripheral arterial prosthetic grafts. J. Vasc. Surg. 8: 147153, 1988.

9）内田發三, 中井幹三, 杉山 悟ほか: 移植血管の 感染. 外科 53:21-27, 1991.

10）鎌田典彦, 佐藤達朗, 山田知行ほか：閉鎖孔ルー トによる腹部ー大腿動脈バイパスを行った人工血 
管感染の一例. 日心外会誌 22: 127-130, 1993.

11）八柳栄治, 笹嶋唯博, 郷一知ほか: 下肢血行再 建術後グラフト感染症例の検討. 日血外会誌 3 : 657-663, 1994.

12) Matin, L.F., Harris, J.M., Fehr, D.M. et al. : Vascular prosthetic infection with Staphylococcus epidermidis: Experimental study of pathogenesis and therapy. J. Vasc. Surg. 9: 464" 471, 1989.

13) Seabrook, G.R., Schmitt, D.D., Bandyk, D.F. et al.: Anastomotic femoral pseudoaneurysm: An investigation of occult infection as an etiologic factor. J. Vasc. Surg. 11: 629-634, 1990.

14) Geary, K.J., Tomkiewicz, Z.M., Harrison, H.N. et al.: Diferential effects of a gram-negative and a gram-positive infection on autogenous and prosthetic grafts. J. Vasc. Surg. 11:339347, 1990.

15) Fletcher, J.P., Dryden, M. and Sorrell, T.C.: Infection of vascular prostheses. Aust. N.Z.J. Surg. 61 : 432-435, 1991.
16) Avramovic, J. and Fretcher, J.P.: Prevention of prosthetic vascular graft infection by rifampicin impregnation of a protein-sealed Dacron graft in combination with parenteral cephalosporin. J. Cardiovasc. Surg. Torino. 33 : 70-74, 1992.

17) Calligaro, K.D., Veith, F.J., Gupta, S.K. et al.: A modified method for management of prosthetic graft infections involving an anastomosis to the common femoral artery. J. Vasc. Surg. 11: 485-492, 1990.

18) Ricotta, J.J., Faggioli G.L., Stella A. et al. : Total excision and extra-anatomic bypass for aortic graft infection. Am. J. Surg. 162 : 145149, 1991.

19）岡本光明, 内藤泰顕, 藤原慶一ほか: 後腹膜腔グ ラフト周囲膿瘍の 3 治験例。 日臨外会誌 55 ： 1030-1034, 1994.

20) Sharp. W.J., Hoballah. J.J., Mohan. C.R. et al. : The management of the infected aortic prosthesis: A current decade of experience. J. Vasc. Surg. 19: 844-850, 1994. 